\title{
The Effect of Financial Performance and Environmental Performance on Firm Value with Islamic Social Reporting (ISR) Disclosure as Intervening Variable in Companies Listed at Jakarta Islamic Index (JII)
}

\author{
Rahma Frida Ratri* and Murdiyati Dewi \\ Economics and Business Faculty, Airlangga University, Indonesia
}

\begin{abstract}
This study examined how far ISR disclosure as the intervening variable could mediate the effect of financial performance and environmental performance on the firm value. The subjects of this study were the companies listed in Jakarta Islamic Index (JII) in 2012-2014. The samples of the study were sixty companies chosen by purposive sampling method, and the analytical technic used path analysis. The results of this study proved that: (1) financial performance had positive effect to the firm value, (2) environmental performance had no effect to the firm value, (3) financial performance had positive effect to the ISR disclosure, (4) environmental performance had positive effect to the ISR disclosure, (5) ISR disclosure had positive effect to the firm value, (6) ISR disclosure could mediate the effect of financial and environmental performances on the firm value.
\end{abstract}

\section{Introduction}

Corporate Social Responsibility (CSR) is a commitment way for the companies to report their social and environmental performances. CSR disclosure cannot be culture free and is attributed primarily to government policy [10. This relationship is based on the companies' role to the stakeholders and the legitimacy of the companies to the society. CSR disclosure can be used as an intermediary to report the firm performance to the stakeholders [12]

The concept of CSR is not only for the conventional economics, but also for shariah economics. The companies listed at shariah index should fulfill the shariah aspects in their operating activity and information disclosure. Now there is Islamic Social Reporting (ISR) concept which is based on Islamic Social Reporting Index (ISRI). This index is the development of the CSR disclosure and match with the shariah principles. The concept of ISR is getting better because of the prior studies on it which discussed the importance of ISR for the Muslim decision makers [4]; [9]; [13] In ISR, the stress on social justice goes beyond reporting the environment, minority interests and employees. It concerns with issues related to the well-being of the society pertaining to interest and unfair trading

\footnotetext{
* Corresponding author: rahmafridaratri@gmail.com
} 
practices such as income distribution or zakat (Othman et al. 2009). The objectives of ISR are to demonstrate accountability to God and community, and to increase transparency of business activities by providing relevant information in conformance to the spiritual needs of Muslims decision makers ([9]The basic constructions of ISR are Tawhid (unity of God) and Shari'a. Tawhid means accepting that God is the ultimate owner of everything on earth and universe (Qur'an 57:5), and man has to be accountable to God (Qur'an 2:28). Shari'a is concerned mainly in promoting social justice and realizing benefits for the people in this world and in the hereafter (al-falah) by setting the basic foundations in every aspect of a Muslim's life including the ethical philosophy [9]

\section{Literature review}

\section{1. Stakeholder theory}

Freeman (1983) changed the definition of shareholder became stakeholder by adding more constituents except shareholders itself (including society and government). The main objective of the stakeholder theory is to help the corporate management in creating the value added from operational activity that they do and minimize the possible loss for corporate stakeholders. Company is not an entity whose operational activity only for their interest but also company has to give benefits for the stakeholders. Going concern of the company depends on the support of the stakeholders so the activity of the company is to look for the stakeholders' support. CSR disclosure has been a successful media to make negotiation to that relationship [8]).

\section{2. Legitimacy theory}

Legitimacy theory focuses on interaction between company and the society. Information disclosure policy depends on the perception of the society to decide the financial and economic resources, so company tends to use the CSR disclosure to influence the perception of the society about that company. Company obeys the norms and rules from the society to get the acceptance from society so the firm value will be increasing. The base of legitimacy theory is "social contract" between company and the society. If the society is not satisfied with the attitude and legitimacy of the company, society can pull back that social contract and threaten the continuity of the company's operational activity (Deegan 2002).

\section{Hypotheses}

Previous studies have found that financial performance significantly effects the firm value. The higher financial performance, the higher firm value [5];[7]. Previous studies also have found that environmental performance significantly effects the firm value. The better environmental performance will give better firm value [1]

H1: Financial performance has significant effect on firm value.

$\mathrm{H} 2$ : Environmental performance has significant effect on firm value.

Previous studies have found that financial performance significantly effects the ISR disclosure. The higher financial performance, the wider ISR disclosure [2[13]; [11]. Previous studies also have found that environmental performance significantly effects the ISR disclosure. The better environmental performance will make the ISR disclosure becomes wider [11].

H3: Financial performance has significant effect on ISR disclosure

H4: Environmental performance has significant effect on ISR disclosure.

Previous studies have found that ISR disclosure significantly effects the firm value. The wider ISR disclosure, the higher firm value (Arshad et al. 2012). Previous studies also 
have found that ISR can be the intervening variable which can mediate the effect of financial and environmental performances on firm [14].

H5: ISR disclosure has significant effect on firm value.

H6: ISR disclosure can mediate the effect of financial performance on firm value.

H7: ISR disclosure can mediate the effect of environmental performance on firm value.

\section{Methodology and results}

\section{1. Sample selection and data collection}

The data used in this research were quantitative data. Data collection procedure was using documentation method. The annual reports of the companies for 3 years period (2012-2014) were collected from the website of Bursa Efek Indonesia on December 15, 2015. The PROPER ranks were collected from the website of Indonesia Ministry of Environment (KLH) on March 6, 2016. The population and sample were the companies listed at Jakarta Islamic Index (JII) in 2012-2014. The companies which are in JII are the selected companies based on these criteria: their operating activities have fulfilled the Islamic principles, have the biggest market capitalization, and have the best liquidity. The sample selection used purposive sampling by setting the criteria. The data gathered were analyzed using SPSS.

Table 1. Population and Sample Selection.

\begin{tabular}{|l|c|c|c|}
\hline \multicolumn{1}{|c|}{ Criteria } & \multicolumn{3}{c|}{ Years } \\
\cline { 2 - 4 } & $\mathbf{2 0 1 2}$ & $\mathbf{2 0 1 3}$ & $\mathbf{2 0 1 4}$ \\
\hline Companies listed at JII & 33 & 32 & 33 \\
\hline Companies were not listed at PROPER ranks & $(11)$ & $(13)$ & $(14)$ \\
\hline Total Companies per Year & 22 & 19 & 19 \\
\hline Total Sample & \multicolumn{3}{|c|}{60} \\
\hline
\end{tabular}

\section{2. Data measurement}

\subsubsection{Islamic Social Reporting (ISR)}

ISR disclosure is measured by Islamic Social Reporting Index (ISRI). The index used based on the prior study by Othman et al. (2009). There are 43 items divided into 6 themes: finance and investment, product and services, employees, environment, and corporate governance. Each item will get score, if that item is disclosed then will get score 1, but if that item is not disclosed then will get score 0 . This is the formula for ISRI:

$$
I S R \text { Index }=\frac{\text { Total Score on Company }}{\text { Maximum Total Score }}
$$

\subsubsection{Financial performance}

The proxy used for financial performance is Return on Assets (ROA). This is the formula for ROA:

$$
\text { Return on Assets }=\frac{\text { Net Income after Tax }}{\text { Total Assets }} \times 100 \%
$$

\subsubsection{Environmental performance}


The proxy used for environmental performance is PROPER ranks. PROPER is a program from Indonesia Ministry of Environment to supervise and control the environmental performance of the companies in Indonesia through information disclosure instrument. The PROPER ranks consist of 5 colors:

$\begin{array}{ll}\text { Gold } & \text { : Very very good } \\ \text { Green } & \text { : Very good } \\ \text { Blue } & \text { : Good } \\ \text { Red } & \text { : Bad } \\ \text { Black } & \text { : Very bad }\end{array}$

\subsubsection{Firm value}

The proxy used for firm value is Tobin's Q. If the point of Tobin's Q is more than 1, it means that company has big competitive advantage so the investment opportunity in that company is also big. This is the formula for Tobin's Q:

$$
\text { Tobin's } Q=\left[\frac{(O S x P)+(D+I)-C A}{T A}\right]
$$

Where: Tobin's Q = Firm Value; OS = Outstanding Shares; $\mathrm{P}=$ Stock Price; $\mathrm{D}=$ Total Debt of Company; I = Total Inventory; $\mathrm{CA}=$ Current Assets; TA = Total Assets

\section{3. Results}

Table 2. The Effect of ROA and PROPER on Tobin's Q.

\begin{tabular}{|c|c|c|c|c|c|c|}
\hline \multicolumn{2}{|c|}{ Model } & \multicolumn{2}{|c|}{ Unstandardized Coefficients } & \multirow{2}{*}{$\begin{array}{c}\begin{array}{c}\text { Standardized } \\
\text { Coefficients }\end{array} \\
\text { Beta }\end{array}$} & \multirow[t]{2}{*}{$\mathrm{t}$} & \multirow[t]{2}{*}{ Sig. } \\
\hline & & $\mathrm{B}$ & Std. Error & & & \\
\hline \multirow{3}{*}{1} & (Constant) & -0.404 & 1.167 & & -0.346 & 0.730 \\
\hline & ROA & 0.274 & 0.031 & 0.799 & 8.883 & 0.000 \\
\hline & PROPER & -0.150 & 0.354 & -0.038 & -0.424 & 0.673 \\
\hline
\end{tabular}

Dependent Variable: TOBINS

Based on the results on Table 2, can be concluded that financial performance (ROA) has significant influence on firm value (TOBINS). This can be seen from Sig. 0,000< significance rate $0,05(5 \%)$. This shows that financial performance significantly influences firm value so $\mathrm{H} 1$ is accepted. Based on the results on Table 2, can be concluded that environmental performance (PROPER) has not significant influence on firm value (TOBINS). This can be seen from Sig. 0,673 > significance rate 0,05 (5\%). This shows that environmental performance does not significantly influence firm value so $\mathrm{H} 2$ is rejected.

Table 3. The Effect of ROA and PROPER on ISR Disclosure.

\begin{tabular}{|c|c|c|c|c|c|c|}
\hline \multicolumn{2}{|c|}{ Model } & \multicolumn{2}{|c|}{ Unstandardized Coefficients } & \multirow{2}{*}{$\begin{array}{c}\begin{array}{c}\text { Standardized } \\
\text { Coefficients }\end{array} \\
\text { Beta } \\
\end{array}$} & \multirow[t]{2}{*}{$\mathrm{t}$} & \multirow[t]{2}{*}{ Sig. } \\
\hline & & $\mathrm{B}$ & Std. Error & & & \\
\hline \multirow[t]{3}{*}{2} & (Constant) & 0.620 & 0.033 & & 18.643 & 0.000 \\
\hline & ROA & 0.004 & 0.001 & 0.457 & 4.080 & 0.000 \\
\hline & PROPER & 0.026 & 0.010 & 0.292 & 2.610 & 0.012 \\
\hline
\end{tabular}

Dependent Variable: ISR

Based on the results on Table 3, can be concluded that financial performance (ROA) has significant influence on ISR disclosure (ISR). This can be seen from Sig. 0,000< significance rate $0,05(5 \%)$. This shows that financial performance significantly influences 
ISR disclosure so H3 is accepted. Based on the results on Table 3, can be concluded that environmental performance (PROPER) has significant influence on ISR disclosure (ISR). This can be seen from Sig. 0,012< significance rate $0,05(5 \%)$. This shows that environmental performance significantly influences ISR disclosure so H4 is accepted.

Table 4. The Effect of ISR Disclosure on Tobin's Q.

\begin{tabular}{|c|c|c|c|c|c|c|}
\hline \multicolumn{2}{|c|}{ Model } & \multicolumn{2}{|c|}{ Unstandardized Coefficients } & \multirow{2}{*}{$\begin{array}{c}\begin{array}{c}\text { Standardized } \\
\text { Coefficients }\end{array} \\
\text { Beta }\end{array}$} & \multirow[t]{2}{*}{$\mathrm{t}$} & \multirow[t]{2}{*}{ Sig. } \\
\hline & & B & Std. Error & & & \\
\hline \multirow[t]{2}{*}{3} & (Constant) & -14.498 & 3.745 & & -3.871 & 0.000 \\
\hline & ISR & 22.677 & 4.906 & 0.519 & 4.622 & 0.000 \\
\hline
\end{tabular}

Dependent Variable: TOBINS

Based on the results on Table 4, can be concluded ISR disclosure (ISR) has significant influence on firm value (TOBINS). This can be seen from Sig. $0,000<$ significance rate $0,05(5 \%)$. This shows that ISR disclosure significantly influences firm value so H5 is accepted.

Table 5. The Mediating Effect.

\begin{tabular}{|c|c|c|c|}
\hline Path & Beta (Indirect Effect) & Beta (Direct Effect) & Total Effect \\
\hline $\mathrm{X} 1 \rightarrow \mathrm{Z} \rightarrow \mathrm{Y}$ & 0,237 & 0,799 & 1,036 \\
\hline $\mathrm{X} 2 \rightarrow \mathrm{Z} \rightarrow \mathrm{Y}$ & 0,152 & $-0,038$ & 0,114 \\
\hline
\end{tabular}

Based on the results on Table 5, can be concluded that ISR disclosure can mediate the effect of financial performance on firm value. This can be seen from Sig. $0,000<$ significance rate $0,05(5 \%)$ and Beta of the indirect effect 0,237 . This shows that ISR disclosure can be used as an intervening variable for the effect of financial performances on firm value so H6 is accepted. Based on the results on Table 5, can be concluded that ISR disclosure can mediate the effect of environmental performance on firm value. This can be seen from Sig. 0,012< significance rate $0,05(5 \%)$ and Beta of the indirect effect 0,152 . This shows that ISR disclosure can be used as an intervening variable for the effect of environmental performance on firm value so $\mathrm{H} 7$ is accepted.

\section{Conclusion}

Based on the results, can be concluded that financial performance has significant influence on firm value. This finding supports the prior studies by [5] and [7]. This indicates that the increasing ROA can increase the value added for the firm. It is also can be concluded that environmental performance does not significantly influence firm value. This finding is consistent with prior study by [14] but inconsistent with prior study by [1]). This indicates that the information about corporate environmental performance in the form of PROPER ranks which is issued by Indonesia Ministry of Environment (KLH) does not significantly influence the value added of the firm.

Based on the results, can be concluded that financial performance has significant influence on ISR disclosure. This finding supports the prior studies by [2], [13], and [11] This indicates that the higher profitability, the wider ISR disclosure. It is also can be concluded that environmental performance has significant influence on ISR disclosure. This finding is consistent with prior study by [11]. This indicates that company who has good environmental performance will tend to disclose it in their ISR disclosure.

Based on the results, can be concluded that ISR disclosure has significant influence on firm value. This finding is consistent with prior studies by [2] and [30] This indicates that the wider ISR disclosure, will increase the trust of the Muslim stakeholders. It is also can be concluded that ISR disclosure can be an intervening variable which can mediate the 
influence of financial performance and environmental performance on firm value. This indicates that ISR disclosure has the important role to mediate the influence of financial performance and environmental performance on firm value.

\section{References}

1. Al-Tuwaijri, Sulaiman A., Theodore E. Christensen \& K.E. Hughes II. The Relation Among Environmental Disclosure, Environmental Performance, and Economic Performance: A Simultaneous Equations Approach. Accounting Organizations and Society, 2: 1-31(2004)

2. Anuar, Hairul A., Maliah Sulaiman \& Nik Nazli Nik Ahmad. Some Evidence of Environmental Reporting by Shariah Compliant Companies in Malaysia. IIUM Journal of Economics and Management, 17(2): 177-208 (2009)

3. Arshad, R, Suaini Othman \& Rohana Othman. Islamic Corporate Social Responsibility, Corporate Reputation and Performance. International Journal of Social, Behavioral, Educational, Economic, Business and Industrial Engineering, 6(4): 643-647 (2012)

4. Baydoun, Nabil \& Roger J. Willett. Islamic Corporate Reports. ABACUS, 36(1): 71-90 (2000)

5. Bidhari, Sandhika C., Ubud Salim \& Siti Aisjah. Effect of Corporate Social Responsibility Information Disclosure on Financial Performance and Firm Value in Banking Industry Listed at Indonesia Stock Exchange. European Journal of Business and Management, 5(18): 39-46 (2013)

6. Deegan, Craig. The Legitimising Effect of Social and Environmental Disclosures - A Theoretical Foundation. Accounting, Auditing \& Accountability Journal, 15(3): 282-311 (2002)

7. Gamayuni, Rindu Rika. The Effect of Intangible Asset, Financial Performance and Financial Policies on the Firm Value. International Journal of Scientific \& Technology Research, 4(1): 202-212 (2005)

8. Gray, R., Reza Kouhy \& Simon Lavers. Corporate Social and Environmental Reporting: A Review of the Literature and a Longitudinal Study of UK Disclosure. Accounting, Auditing, \& Accountability Journal, 8(2): 47-77 (1995)

9. Haniffa, R. Social Reporting Disclosure - An Islamic Perspective. Indonesian Management \& Accounting Research, 1: 128-146 (2002)

10. Haniffa, R.M. \& T.E. Cooke. The Impact of Culture and Governance on Corporate Social Reporting. Journal of Accounting and Public Policy, 24: 391-430 (2005)

11. Maulida, Aldehita P., Agung Yulianto \& Asrori. Analisis Faktor-faktor yang Mempengaruhi Pengungkapan Islamic Social Reporting (ISR). Simposium Nasional Akuntansi XVII. Mataram (2014)

12. Nurlela, R \& Islahuddin. Pengaruh Corporate Social Responsibility terhadap Nilai Perusahaan dengan Prosentase Kepemilikan Manajemen sebagai Variabel Moderating. Simposium Nasional Akuntansi XI. Pontianak (2008)

13. Othman, R., Azlan Md. Thani \& Erlane K. Ghani. Determinants of Islamic Social Reporting Among Top Shariah-Approved Companies in Bursa Malaysia. Research Journal of International Studies, 12(10): 4-20 (2009)

14. Rahmawati, A’la \& Tarmizi Achmad. Pengaruh Kinerja Lingkungan terhadap Financial Corporate Performance dengan Corporate Social Responsibility Disclosure sebagai Variabel Intervening. Diponegoro Journal of Accounting, 1(2): 1-15 (2012) 